\title{
3 Research Square \\ Polyphasic Taxonomy of Four Passalora-like Taxa Occurring on Fruit and Forest Trees
}

Mounes Bakhshi ( $\triangle$ mounesbakhshi@gmail.com )

Iranian Research Institute of Plant Protection https://orcid.org/0000-0002-8404-1357

\section{Rasoul Zare}

Iranian Research Institute of Plant Protection

\section{Uwe Braun}

Martin Luther Universität Halle-Wittenberg: Martin-Luther-Universitat Halle-Wittenberg

Hossein Taheri

Iranian Research Institute of Plant Protection

\section{Research Article}

Keywords: Cercosporoid fungi, Iran, leaf spot, multi-gene phylogeny, Mycosphaerellaceae, new taxa

Posted Date: June 3rd, 2021

DOI: https://doi.org/10.21203/rs.3.rs-540071/v1

License: @ (i) This work is licensed under a Creative Commons Attribution 4.0 International License. Read Full License 


\section{Abstract}

Species of Passalora s. lat. are eminent phytopathogenic fungi that cause generally leaf spot diseases on a broad variety of plants throughout the world. During our investigations exploring cercosporoid fungi associated with leaf spot symptoms of fruit and forest trees in northern and north-western Iran, several passalora-like infections were isolated from symptomatic leaves of different trees belonging to the Fabaceae, Malvaceae, Rosaceae and Ulmaceae. A polyphasic taxonomic approach by applying molecular data, morphological features and host data, was employed to identify the isolates. In a multigene phylogenetic analysis (LSU, ITS and RPB2), these isolates clustered in four clades in the Mycosphaerellaceae. The revealed taxa encompass Paracercosporidium microsorum on Tilia platyphyllos, Prathigadoides gleditsiae-caspicae gen. et. sp. nov. on Gleditsia caspica, Pruniphilomyces circumscissus on Prunus avium and Prunus cerasus, and Sirosporium celtidis on Celtis australis. The new genus Prathigadoides and its type species Prathigadoides gleditsiae-caspicae are molecularly distinct from all phylogenetically related genera, and some characteristics of the conidiophores and conidia differs from those of the morphologically similar species Prathigada condensata on the North America Gleditsia triacanthos.

\section{Introduction}

The Mycosphaerellaceae is a large and diverse family in the order Mycosphaerellales, class Dothideomycetes (Crous et al. 2009; Abdollahzadeh et al. 2021). Since the first molecular study on the Mycosphaerellaceae (Stewart et al. 1999), the concept of the family and its genera has been significantly revised and recently, based on phylogenetic data, 122 asexual and sexual genera have been accepted within this family (Videira et al. 2017; Crous et al. 2020). Most of the asexual morphs connected with this family are cercosporoid fungi (Braun et al. 2013). Based on a mainly morphological approach, Crous and Braun (2003) reduced the true cercosporoids to four genera, viz. Cercospora Fresen. ex Fuckel, Pseudocercospora Speg., Passalora Fr. and Stenella Syd. Recent phylogenetic examinations of cercosporoid fungi have revealed that these genera are polyphyletic. Pantospora Cif. (Minnis et al. 2011; Braun et al. 2013), Pallidocercospora Crous, Paracercospora Deighton (Crous et al. 2013), Phaeocercospora Crous (Crous et al. 2012) are genera belonging to the Pseudocercospora complex. They are morphologically generally similar to or only somewhat different from Pseudocercospora, but they were clearly segregated on the basis of phylogenetic data as distinct genera (Crous et al. 2013; Hyde et al. 2013). Despite the previous assumption of the monophyly of the genus Cercospora (Groenewald et al. 2013; Bakhshi et al. 2015a), Bakhshi et al. (2015b) introduced the genus Neocercospora M. Bakhshi, Arzanlou, Babai-ahari \& Crous, characterized by being morphologically cercospora-like, but clustering in a separate clade in Mycosphaerellaceae apart from Cercospora s. str. Regarding the genus Stenella, sequencing of the type species (S. araguata Syd.) revealed that it belongs to Teratosphaeriaceae, and the remaining species in Mycosphaerellaceae. Most former mycosphaerellaceous Stenella species were assigned to Zasmidium, an old genus name, other species were placed in new genera (e.g., 
Pseudozasmidium Videira \& Crous, Videira et al. 2017). The phylogenetic structure of Passalora is, however, more complicated than the other cercosporoids.

The genus Passalora was originally described by Fries (1849) based on Passalora bacilligera Mont. \& Fr., a fungus occurring on the forest tree Alnus glutinosa (L.) Gaertn. The delimitation of species within the genus as well as the circumscription of the genera, has changed since its establishment. A full discussion on the history of taxonomy of passalora-like taxa was presented in Braun et al. (2013). Recent phylogenetic analyses based on a much broader sampling, including the type species of Passalora and its synonymized genera, revealed that Passalora s. str. forms a well-supported clade in the Mycosphaerellaceae and includes only the type species )Videira et al. 2017). As a consequence, Videira et al. (2017) resurrected several old generic names, which were previously merged with Passalora based on morphology (Crous and Braun 2003), and described many additional new genera which comprise passalora-like species. On the other hand, some Passalora species clustered within the Cercospora or Pseudocercospora clade (Groenewald et al. 2013; Videira et al. 2017). Therefore, previous generic definitions of cercosporoid fungi (Crous and Braun 2003) can no longer be applied to these genera in their current circumscriptions (Videira et al. 2017), and the identification of passalora-like taxa strongly depends on the availability of DNA sequence data.

Species of Passalora s. lat. are mostly well-known phytopathogenic fungi that cause typical leaf spots, necrosis, or chlorosis, on a wide range of woody and herbaceous host plants growing in semi-arid or wet environments under a wide range of climates (Chupp 1954; Crous and Braun 2003; Videira et al. 2017), while some display endophytic (Douanla-meli et al. 2013) or mycophylic life styles (Braun et al. 2013; Videira et al. 2017). Passalora-like fungi include important plant pathogenic species, such as Nothopassalora personata (Berk. \& M.A. Curtis) U. Braun, C. Nakash., Videira \& Crous (syn. Passalora personata), the causal agent of late leaf spot disease on peanut (Clevenger et al. 2018; Bakhshi and Zare 2020), Passalora vaginae (W. Krüger) U. Braun \& Crous causing a foliar disease on Saccharum officinarum L. (Crous and Braun 2003), Passalora sequoia (Ellis \& Everh.) Y.L. Guo \& W.H. Hsieh, a needle blight disease of Cupressocyparis leylandii (A.B.Jacks. \& Dallim.) Dallim. (Williams-Woodward \& Copes 2017), Fulvia fulva (Cooke) Cif. (syn. Passalora fulva), responsible for tomato leaf mold (Thomma et al. 2005) and Passalora spp. associated with a leaf spot disease of Ficus spp. (Singh et al. 2012). Some species are considered potential biocontrol agents of weeds, including Passalora ageratinae Crous \& A.R. Wood on Ageratina adenophora (Spreng.) R.M. King \& H. Rob. (Heystek et al. 2011) and Passalora stromatica A.F. Fern. \& R.W. Barreto on Tithonia diversifolia (Hemsl.) A. Gray (Fernandes et al. 2013). A few species are mycophylic e.g. P. acori (J.M. Yen) U. Braun \& Crous on Uromyces sparganii Cooke \& Peck and P. uromycestri (Pollack) U. Braun \& Crous on Uromyces cestri Mont. (Braun et al. 2013). Owing to the strong relevance of such diseases in agriculture, horticulture and forestry, the understanding and stabilizing the taxonomy of the species of the genus Passalora s. lat. is, therefore, of particular importance.

The mainland of Iran is well-known as an area with enormous biodiversity, including a very wide range of vascular plants which are the basis for a huge diversity of foliicolous fungi, including cercosporoid 
hyphomycetes. Some genera of cercosporoid fungi of Iran, e.g. Cercospora (Bakhshi et al. 2015a, 2015b, 2018; Bakhshi 2019; Bakhshi and Zare 2020) and Pseudocercospora (Bakhshi et al. 2014; Braun et al. 2020), have been relatively well-documented in recent years based on recent molecular revisions of these genera (Groenewald et al. 2013; Crous et al. 2013). Nevertheless, except for Nothopassalora personata (Bakhshi and Zare 2020), no molecular studies have so far been conducted on other passalora-like species known from Iran. The aim of this study was to characterize passalora-like taxa associated with some fruit and forest trees in the northern zone of Iran, in terms of morphology, cultural characteristics, ecology, and DNA phylogeny.

\section{Material And Methods}

\section{Sample collection and isolates}

Plant samples with cercosporoid leaf spot symptoms were collected in Iran from different biotopes, including natural forests and agricultural orchards. Fresh samples were immediately taken to the laboratory in paper bags. To establish axenic cultures originating from single conidia, samples were examined under a Zeiss Stemi 305 (Carl Zeiss, Jena, Germany) stereo-microscope and cercosporoid conidia from lesions were suspended in sterilized distilled water and spread on malt-extract agar (MEA; Fluka, Hamburg, Germany) medium using a flame-sterilized micro-spatula as explained in Bakhshi et al. (2021). Representative axenic cultures were deposited in culture collection of the Iranian Research Institute of Plant Protection (IRAN C), Tehran, Iran, and the Westerdijk Fungal Biodiversity Institute (formerly CBS), Utrecht, The Netherlands. Diseased plant specimens were dried in a plant press and deposited in fungal herbarium of the Iranian Research Institute of Plant Protection (IRAN F).

\section{DNA isolation, amplification and sequencing}

Genomic DNA was extracted from mycelium on MEA medium at $25^{\circ} \mathrm{C}$ in the dark for three weeks using the protocol of Möller et al. (1992). DNA samples were subsequently diluted 70 times in preparation for further DNA amplification reactions. Amplification and sequencing of seven nuclear loci, i.e. 28S nrRNA gene (LSU), internal transcribed spacer regions and intervening 5.8S nrRNA gene (ITS) of the nrDNA operon, actin $(A C T)$, translation elongation factor 1-a (TEF1- $a)$, calmodulin (CAL), histone $\mathrm{H} 3(H I S)$, and DNA-directed RNA polymerase II second largest subunit (RPB2) were performed with primers LROR + LR5 (Vilgalys \& Hester 1990), V9G (De Hoog \& Gerrits van den Ende 1998) + ITS4 (White et al. 1990), ACT512F + ACT-783R (Carbone and Kohn 1999), EF1-728F (Carbone and Kohn 1999) + EF-2 (O'Donnell et al. 1998), CAL-228F (Carbone and Kohn 1999) + CAL-2Rd (Groenewald et al. 2013), CYLH3F + CYLH3R (Crous et al. 2004b), and RPB2-5F2 (Sung et al. 2007)/ RPB2-f5f + fRPB2-7cR (Liu et al. 1999), respectively. PCR reaction mixtures and conditions outlined by Bakhshi et al. $(2014,2015 a)$ were followed for standard amplification and subsequent sequencing of the LSU, ITS, ACT, TEF1-a, CAL and HIS loci. The RPB2 PCR mixture consisted of 10-15 ng genomic DNA, 1× PCR buffer (SinaClon, Iran), $2 \mathrm{mM}$ $\mathrm{MgCl} 2$ (SinaClon), $50 \mu \mathrm{M}$ of each dNTP, $0.7 \mu \mathrm{L}$ DMSO, $0.28 \mu \mathrm{M}$ of each primer and 0.5 Unit GoTaq ${ }^{\circledR}$ Flexi 
DNA polymerase (SinaClon). To obtain the partial RPB2, a touchdown PCR protocol was used: initial denaturation $\left(94^{\circ} \mathrm{C}, 5 \mathrm{~min}\right), 5$ amplification cycles $\left(94^{\circ} \mathrm{C}, 45 \mathrm{~s} ; 58^{\circ} \mathrm{C}, 45 \mathrm{~s} ; 72^{\circ} \mathrm{C}, 90 \mathrm{~s}\right), 5$ amplification cycles $\left(94^{\circ} \mathrm{C}, 45 \mathrm{~s} ; 56^{\circ} \mathrm{C}, 45 \mathrm{~s} ; 72^{\circ} \mathrm{C}, 90 \mathrm{~s}\right), 30$ amplification cycles $\left(94^{\circ} \mathrm{C}, 45 \mathrm{~s} ; 52^{\circ} \mathrm{C}, 45 \mathrm{~s} ; 72^{\circ} \mathrm{C}, 90 \mathrm{~s}\right)$, and a final extension $\left(72^{\circ} \mathrm{C}, 7 \mathrm{~min}\right)$. Subsequent sequencing was performed in both directions using the $\mathrm{PCR}$ primers by Microsynth Company (Balgach, Switzerland).

\section{Phylogenetic analyses}

The raw trace files were inspected and edited with MEGA v. 6 software (Tamura et al. 2013) and consensus sequences were manually generated from the forward and reverse sequences. Following blast searches of the NCBI's GenBank nucleotide database for preliminary identifications, a multi-gene tree was constructed using LSU, ITS and RPB2 sequences from Mycosphaerellaceae taxa (Videira et al. 2017; Crous et al. 2020). At first, the alignments for each locus were performed by MAFFT v. 7 (http://mafft. cbrc.jp/alignment/server/) (Katoh and Standley 2013) followed by manual adjustments using MEGA v. 6. Multiple alignments were combined with Mesquite v. 3.61 (Maddison and Maddison 2018). Phylogenetic reconstructions of the combined gene trees were performed using Maximum Parsimony (MP) and Bayesian Inference (BI) criteria.

Maximum Parsimony analysis was performed in PAUP v. 4.0 (Swofford 2003) and involved 10,000,000 replicates of fast stepwise search option using the tree bisection reconnection (TBR) as the branchswapping algorithm with 100 random sequence additions. All characters were unordered and given equal weight and alignment gaps were treated as fifth character state. Branches of zero length were collapsed and all multiple, equally most parsimonious trees were saved. Tree length $(\mathrm{TL})$, consistency index $(\mathrm{Cl})$, retention index $(\mathrm{RI})$, rescaled consistency index $(\mathrm{RC})$ and homoplasy index $(\mathrm{HI})$ were calculated for the resulting tree. For Bayesian phylogenetic reconstruction, the best fit evolutionary models were selected independently for each locus using MrModeltest v. 2.3 (Nylander 2004) and applied to each gene partition. Bayesian inference analysis (BI) was conducted with MrBayes v. 3.2.6 (Ronquist et al. 2012) by Markov Chain Monte Carlo sampling (MCMC) in two parallel runs for a maximum of $10,000,000$ generations and trees were sampled every $100^{\text {th }}$ generation. The analyses were stopped when the two runs converged and the average standard deviation of split frequencies came below 0.01 . The first $25 \%$ of generated trees representing the burn-in phase were discarded and the remaining trees were used to calculate posterior probabilities of the majority rule consensus tree. Phylogenetic trees were visualised with Geneious v. 8.1 .8 (Kearse et al. 2012) and edited in Adobe $®$ Illustrator v. CC 2017. The new sequences generated in this study were deposited in NCBI's GenBank nucleotide database (www.ncbi.nlm.nih.gov) and the alignments and phylogenetic trees in TreeBASE (Study ID S28243) (www.TreeBASE.org). The accession numbers of the sequences used for the phylogenetic analyses are listed in Table 1.

\section{Morphology}


Detailed morphological descriptions are provided for all taxa based on structures observed in herbarium material. Specimens were processed and examined with a Zeiss Stemi 305 stereo-microscope, and fungal structures (stromata, hyphae, conidiophores and conidia) were mounted on glass slides in clear lactic acid for microscopic studies and microphotography. Specimens were examined with an Olympus BX51 (Olympus, Tokyo, Japan) light microscope with differential inference contrast (DIC) illumination at $\times 1000$ magnification and photographed with an Olympus DP25 camera fitted to the microscope. Size ranges of morphological characters were derived from at least 30 measurements and images used for figures processed with Adobe Photoshop CS5 (Adobe Systems, United States).

Colony morphology on MEA was determined after 20 days at $25^{\circ} \mathrm{C}$ in the dark in duplicate and colony color was described using the mycological color charts of Rayner (1970). Nomenclatural novelties and descriptions were deposited in MycoBank (www.mycobank.org; Crous et al. 2004a).

\section{Results}

\section{Molecular phylogenetic analyses}

The final concatenated alignment comprised of 130 ingroup taxa within the family Mycosphaerellaceae, with 2250 characters including alignment gaps (gene boundaries of LSU: 1-745, RPB2: 746-1554 and ITS: 1556-2250). The five characters artificially introduced as spacers between partitions were excluded from the phylogenetic analysis. Schizothyrium pomi (Mont.) Arx (isolate CBS 486.50) (Schizothyriaceae) was used as outgroup (Fig. 1).

Phylogenetic trees obtained from BI and MP analyses yielded trees with similar overall topologies at the generic level and are in agreement with previous studies, such as Videira et al. (2017). The results of MrModeltest recommended that Bayesian analysis should use dirichlet $(1,1,1,1)$ state frequencies and the GTR+I+G with an invgamma-shaped rate variation for all loci (LSU, RPB2 and ITS). The Bayesian analysis resulted in 4942 trees after 2,470,000 generations. The first 1234 trees, representing the burn-in phase of the analyses, were discarded, while the remaining 3708 trees were used for calculating posterior probabilities (PP) in the majority rule consensus tree (Fig. 1). The alignment contained a total of 1230 unique site patterns $(217,557$ and 456 for LSU, RPB2 and ITS, respectively).

The Maximum Parsimony (MP) analyses generated a maximum of 1000 equally most parsimonious trees and the bootstrap support values (MP-BS) were mapped on the Bayesian tree as the second value in the tree nodes (Fig. 1). From the analyzed characters, 1074 were constant, 206 were variable and parsimony-uninformative and 970 were parsimony-informative. A parsimony consensus tree was calculated from the equally most parsimonious trees and the branches were mapped with a thicker line on the Bayesian tree (Length $=14,442, \mathrm{Cl}=0.170, \mathrm{RI}=0.500, \mathrm{RC}=0.085, \mathrm{HI}=0.830$ ).

\section{Taxonomy}


Based on phylogenetic analyses, the isolates collected in this study could be assigned to four different taxa in the Mycosphaerellaceae. The taxa are treated as follows.

Paracercosporidium microsorum (Sacc.) U. Braun, C. Nakash., Videira \& Crous, Fig. 2

Description in planta:Leaf spots amphigenous, irregular to subcircular, dark brown to black, sometimes with yellow halo, 1-4 mm diam. Mycelium internal. Stromata small, substomatal to intraepidermal, brown, up to $45 \mu \mathrm{m}$ diam. Caespituli amphigenous, pale brown, effuse. Conidiophores aggregated in loose fascicles, emerging from upper part of stromata, medium brown, smooth to slightly verruculose, 0 3-septate, unbranched, thick-walled, cylindrical, subcylindrical to geniculate-sinuous, irregular in width, frequently constricted due to sympodial proliferation, (15-)30-75 ×4-5.5 $\mu \mathrm{m}$. Conidiogenous cells integrated, terminal or intercalary, polyblastic, proliferating sympodially, with conidiogenous loci rim-like, darkened and thickened, located at shoulders and at the apex, 1.5-2.5 $\mu \mathrm{m}$ diam. Conidia solitary, hyaline to pale brown, cylindrical to obclavate, obconically truncated and thickened at the base, rounded at the apex, 22-58 × 4-7 $\mu \mathrm{m}, 1-6$-euseptate, hila thickened and darkened, 1.5-2.5 $\mu \mathrm{m}$ diam.

Cultural characteristics: Colonies on MEA, surface raised, folded, white in the centre, pink vinaceous towards the rim, with sparse aerial mycelium and lobate margin, reverse dark brown, reaching $11 \mathrm{~mm}$ after 20 days at $25^{\circ} \mathrm{C}$.

Material examined: Iran: Mazandaran Province, Nowshahr, Mollakola, N 36³2'20", E 5148'31", alt. 260 m, on leaves of Tilia platyphyllos Scop. (Malvaceae), 11 November 2019, M. Bakhshi, IRAN 18054F, IRAN 4116C ( TEF1- $a=X X X)$, IRAN 18055F, IRAN 4089C ( TEF1- $a=X X X)$, IRAN 4074C, IRAN 18056F, IRAN 4118C $(T E F 1-\alpha=\mathrm{XXX})$.

Notes: To our knowledge, this study is the first molecular confirmation of Paracercosporidium microsorum for Asia and part of the TEF1-a locus was sequenced for the first time for this species.

Prathigadoides M. Bakhshi, Zare \& U. Braun gen. nov.

\section{MycoBank MB XXXXX.}

Etymology. Composed of Prathigada, a genus name used for morphologically similar species, and the Latin suffix -oides (similar).

Type species.Prathigadoides gleditsiae-caspicae M. Bakhshi, Zare \& U. Braun sp. nov.

Description: Plant pathogenic. Caespituli amphigenous. Conidiophores fasciculate, arising from a welldeveloped, substomatal to intraepidermal, semi-immersed, brown stroma, medium to dark brown, finely roughened, septate, unbranched, straight, slightly curved or geniculate-sinuous, subcylindrical, wall thickened. Conidiogenous cells integrated, terminal, finely roughened, polyblastic, proliferating sympodially, with conidiogenous loci thickened, darkened and protuberant. Conidia solitary, brown, subcylindrical to obclavate, usually distinctly rostrate, straight to gently curved, smooth to rough-walled, 
wall thickened, apex subobtuse to obtuse, base truncated to short obconically truncated, septate; hila thickened and darkened.

Prathigadoides gleditsiae-caspicae M. Bakhshi, Zare \& U. Braun sp. nov. Fig. 3

\section{MycoBank MB XXXX.}

Etymology. Epithet derived from the host species of this fungus, Gleditsia caspica.

Holotype. Iran: Guilan Province, Talesh, Kishonben, on Gleditsia caspica L. (Fabaceae), 12 October 2012, M. Bakhshi (IRAN 16460F).

EX-type strain: CBS 136121. GenBank: $A C T=\mathrm{XXX} ; C A L=\mathrm{XXX} ; H I S=\mathrm{XXX} ; T E F 1-a=\mathrm{XXX}$.

Description in planta: Leaf spots amphigenous, circular to subcircular, 1-4 mm diam., grey in center, with brown margin, occasionally with shot-holes in the centers. Mycelium internal. Stromata well-developed, substomatal to intraepidermal, semi-immersed, brown, 25-75 $\mu \mathrm{m}$ diam. Caespituli amphigenous. Conidiophores aggregated in loose to dense fascicles, erumpent through the cuticle or emerging through stomata, medium to dark brown, finely roughened, 0-3-septate, unbranched, straight, slightly curved or geniculate-sinuous, subcylindrical, wall thickened, regular in width, $(25-) 40-55(-80) \times(3.5-) 4-5 \mu \mathrm{m}$. Conidiogenous cel/s integrated, terminal, medium brown, finely roughened, polyblastic, proliferating sympodially, with conidiogenous loci thickened, darkened, protuberant and somewhat refractive, located at the apex and on shoulders formed by sympodial proliferation, 2-3.5 $\mu \mathrm{m}$ diam. Conidia solitary, brown, subcylindrical to obclavate, usually rostrate, straight to gently curved, smooth to rough-walled, wall thickened, apex subobtuse to obtuse, base truncated to short obconically truncated, (4-)10-16-septate, occasionally constricted at the septa, $(42-) 65-76(-110) \times(4.5-) 5.5-6 \mu \mathrm{m}$; hila thickened, darkened and refractive, $1-2 \mu \mathrm{m}$ diam.

Cultural characteristics: Colonies on MEA, surface raised, folded, dark brown-grey, with sparse aerial mycelium and irregular margin, reverse dark brown, reaching $7 \mathrm{~mm}$ after 20 days at $25^{\circ} \mathrm{C}$.

Additional material examined: Iran: Guilan Province, Gourab Zarmikh, N 37¹8'02", E 49¹2'39", on Gleditsia caspica, 7 August 2019, M. Bakhshi (IRAN 18053F, IRAN 4110C, IRAN 4111C); Guilan Province, Talesh, Kishonben, on Gleditsia caspica, October 2020, M. Bakhshi (P 829).

Notes: The cercosporoid fungus found in Iran on the endemic Gleditsia capsica, distributed in a small area near the southern coast of the Caspian See, proved to belong to a clade of its own distinct from all other clades within the Mycosphaerellaceae, which reflects a new undescribed genus. The type species of the new genus is morphologically close to Prathigada condensata (Ellis \& Kellerm.) U. Braun [ ${ }^{\circ}$ Cercospora condensata Ellis \& Kellerm, Passalora condensata (Ellis \& Kellerm.) U. Braun] on the North American Gleditsia triacanthos L., but differs in having finely verruculose conidiophores with wider conidiogenous loci, 2-3.5 $\mu \mathrm{m}$ diam., and shorter conidia, (42-)65-76(-110) $\mu \mathrm{m}$ long, with numerous dense septa [(4-)10-16], and narrower hila, 1-2 um diam. [versus, smooth conidiophores with narrower 
loci, 1.5-2.5 $\mu \mathrm{m}$ diam., and longer conidia, 40-150 $\mu \mathrm{m}$ long, with fewer, more spaced septa, 4-12, and larger hila, 2-2.5 $\mu \mathrm{m}$ diam. (Braun et al. 2013)]. Furthermore, the two hosts species, G. capsica and G. triacanthos, are geographically and phylogenetically clearly distinct. Gleditsia capsica belongs to the Asian G. japonica clade, which is distantly related to the G. triacanthos clade (Schnabel et al. 2003). In spite of the strong morphological similarity between the new species from Iran and species previously assigned to Prathigada, the latter genus is not available for the fungus on Gleditsia capsica. Based on phylogenetic examinations of the type species of Prathigada, P. cratevae (Syd. \& P. Syd.) Subram., this genus was reduced to synonymy with Pseudocercospora (Braun et al. 2013). The conidiogenous loci and hila in the type species of Prathigada are conspicuous by being rigid and refractive, falling into the morphological variation of Pseudocercospora spp., but they are not truly thickened. The loci in Cercospora condensata are thickened and somewhat similar to those of Prathigadoides gleditsiaecaspicae, suggesting that the two species might be congeneric. However, the clarification of this question requires results of phylogenetic analyses of $C$. condensata. In any case, the North American cercosporoid species on G. triacanthos neither pertain to Cercospora nor to Passalora in the current sense and circumscription (Videira et al. 2017).

\section{Pruniphilomyces circumscissus(Sacc.) Crous \& Bulgakov, Fig. 4}

Description in planta:Leaf spots amphigenous, circular to subcircular, 1-6 mm diam., pale brown to brown with distinct border. Mycelium internal. Stromata well-developed, substomatal to intraepidermal, semi-immersed, brown, 20-55 $\mu \mathrm{m}$ diam. Caespituli amphigenous. Conidiophores aggregated in loose to moderately dense fascicles, arising from stomata or erumpent through the cuticle, medium brown, smooth to slightly verruculose, 0-3-septate, unbranched, straight to geniculate-sinuous, subcylindrical, regular in width, (30-)38-49(-60) × 3-4.5 $\mu \mathrm{m}$. Conidiogenous cells integrated, terminal, medium brown, polyblastic, proliferating sympodially, with conidiogenous loci thickened, darkened and refractive and located at the apex and shoulders, 1-2 $\mu \mathrm{m}$ diam. Conidia solitary, medium olivaceous brown, subcylindrical to obclavate, abruptly tapered towards the apex, straight to gently curved, apex subobtuse to obtuse, base obconically truncated, 1-7(-10)-septate, (18-)50-65(-105) × (3-)3.5-5 $\mu \mathrm{m}$; hila thickened, darkened and refractive, 1-2 $\mu \mathrm{m}$ diam.

Cultural characteristics: Colonies on MEA, surface flat, folded, with moderate aerial mycelium and entire margin, dark olivaceous green, reverse olivaceous black, reaching $20 \mathrm{~mm}$ after 20 days at $25^{\circ} \mathrm{C}$.

Material examined: Iran: Mazandaran Province, Kelardasht, Goharkela, N 36²8'59.04", E 51¹4'58.68", alt. 1300 m, on Prunus avium L. (Rosaceae), 12 August 2018, M. Bakhshi (IRAN 18026F, IRAN 3478C), on Prunus avium, September 2020, M. Bakhshi (IRAN XXXF, P 943.a). Mazandaran Province, Marzan Abad, Foshkour, N 36²1'29.2", E 51¹1'43.04", alt. 1770 m, on Prunus avium, 12 August 2018, M. Bakhshi (IRAN 3477C), on Prunus avium, September 2020, M. Bakhshi (IRAN XXXF, P 947). Iran: Ardabil Province, Moghan, on Prunus avium, October 2012, M. Bakhshi (IRAN 16459F, CBS 136122 = IRAN 2681C). Iran: West Azerbaijan Province, Kaleibar, on Prunus avium, November 2012, M. Arzanlou (IRAN 18022F, P 237). West Azerbaijan Province, Khoy, Firouragh, on Prunus cerasus L. November 2011, M. Arzanlou (IRAN 
2656C). Iran: Guilan Province, Talesh, Lisar, on Prunus avium, May 2019, P. Emdadi (IRAN 18043F, IRAN 4099C). Talesh, Jowkandan, on Prunus avium, May 2019, M. Bakhshi (IRAN 18021F, P 830). GenBank numbers CBS 136122: $A C T=\mathrm{XXX} ; C A L=\mathrm{XXX} ; H I S=\mathrm{XXX} ;$ TEF1 $-a=\mathrm{XXX}$.

Notes: To our knowledge, this study is the first molecular confirmation of Pruniphilomyces circumscissus for the Middle East. Furthermore, part of the ACT, TEF1- $a, C A L$ and HIS loci is sequenced for the first time in this species.

Sirosporium celtidis (Biv.) M.B. Ellis, Fig. 5

Description in planta:Leaf spots amphigenous, subcircular to circular, olivaceous, reddish brown to dark blackish brown, velvety, 1-9 mm diam., without forming chlorosis or necrosis, which might be due to the semibiotrophic nature of the fungus. Caespituli hypophyllous, velvety. Stromata lacking. Mycelium partly immersed and partly external; consisting of branched, septate (septa 10-19 $\mu \mathrm{m}$ apart), pale brown to brown hyphae, 2.5-4 $\mu \mathrm{m}$ wide, smooth or somewhat verrucose, faintly rough-walled. Conidiophores arising from external hyphae, macronematous or semi-macronematous, solitary, not branched, dark brown, thick-walled, 0-1(-4)-septate, constricted at the septa, $0-2$ times geniculate, 13-22(-30) $\times$ (4-) 6-8 $\mu \mathrm{m}$, often reduced to solitary conidiogenous cells. Conidiogenous cells terminal and lateral, proliferating sympodially, brown, smooth or verrucose, 5-10(-19) $\times(4-) 6-8 \mu \mathrm{m}$, loci thickened and darkened, 2-5 $\mu \mathrm{m}$ diam. Conidia solitary, brown to dark brown, subcylindrical to obclavate, straight to curved or coiled, thick-walled, smooth, rugulose or verrucose, (2-)11-16(-31) transversely septate and occasionally with 1-3 longitudinal or oblique septa, often constricted at the septa, apex rounded, base rounded to truncated, $\left(15^{-}\right) 62-85(-130) \times(4-) 6-7(-9) \mu \mathrm{m}$; hila rather inconspicuous, but thickened and somewhat darkened, $2-5 \mu \mathrm{m}$ diam.

Cultural characteristics: Colonies on MEA, surface brown-grey, with sparse aerial mycelium and entire margin, colony surrounded by a red-brown halo, reverse dark brown, reaching $4 \mathrm{~mm}$ after 20 days at $25^{\circ} \mathrm{C}$.

Material examined: Iran: Mazandaran Province, Jannat Roudbar, Dalkhani forest, N 36 49'10.49", E 5040'05.06", alt. 660 m, on Celtis australis L. (Ulmaceae), 14 August 2018, M. Bakhshi \& H. Taheri (IRAN 18030F, IRAN 3483C, IRAN 3484C). Mazandaran Province, Nowshahr, Mollakola, alt. 260 m, N 36³2'20", E 51 ${ }^{\circ} 48^{\prime} 31^{\prime \prime}$, on leaves Celtis australis, 11 November 2019, M. Bakhshi (IRAN 18057F, IRAN 4117C, P 899.a). Iran: West Azerbaijan Province, Kaleibar, on Celtis australis, 10 November 2012, M. Arzanlou (IRAN 16465F, CBS 136019). GenBank numbers CBS 136019: ACT =XXX;CAL =XXX; HIS=XXX; TEF1- $a=\mathrm{XXX}$.

Notes: To our knowledge, this study is the first molecular confirmation of Sirosporium celtidis for Asia. Furthermore, first sequences of the ACT, TEF1- $a, C A L$ and HIS loci have also been generated for this species.

\section{Discussion}


The present study aimed at identifying passalora-like strains associated with fruit and forest trees from the northern and northwestern zones of Iran based on a combination of DNA phylogeny, host range, ecology and morphological characteristics. Members of Passalora s. lat. are devastating plant pathogens on a wide range of economically important woody and herbaceous plants worldwide, including Iran (Crous and Braun 2003; Thomma et al. 2005; Singh et al. 2012; Fernandes et al. 2013; Bakhshi and Zare 2020). Recent developments in the phylogeny of the Mycosphaerellacea have revealed the polyphyly of Passalora s. lat., and the distribution of passalora-like clades throughout the Mycosphaerellaceae (Videira et al. 2017; Crous et al. 2020). As a consequence, several generic names with passaloroid morphology, previously reduced to synonymy with Passalora (Crous and Braun 2003), e.g., Cercosporidium Earle, Fulvia Cif., Mycovellosiella Rangel, Phaeoramularia Munt-Cvetk. and Ragnhildiana Solheim, have been reinstated and many additional new genera, e.g., Pleuropassalora U. Braun, C. Nakash., Videira \& Crous, Graminopassalora U. Braun, C. Nakash., Videira \& Crous, Coremiopassalora U. Braun, C. Nakash., Videira \& Crous and Neocercosporidium Videira \& Crous, etc., have been described. Some of these genera, e.g., Exopassalora Videira \& Crous, clustered within the Phaeothecoidiellaceae clade (Videira et al. 2017). There are very few distinctive morphological features at generic level within the Passalora complex and most of these genera are morphologically similar to or somewhat even indistinguishable from Passalora s. str. (Videira et al. 2017).

Among taxa of Passalora s. lat. known from Iran (Bakhshi et al. 2012; Pirnia 2019), so far only the identity of one species, Nothopassalora personata, has been confirmed based on DNA sequence data (Bakhshi and Zare 2020). During the course of the present study, passalora-like fungi associated with leaf spot symptoms of different trees of the Fabaceae, Malvaceae, Rosaceae, and Ulmaceae were subjected to a multi-gene phylogeny (LSU, ITS and RPB2). According to our findings, these isolates clustered in four different genus clades in the Mycosphaerellaceae, of which one taxon was associated with cherry fruit trees (Prunus spp.) and the three remaining taxa were associated with forest trees.

Recently, Crous et al. (2020) studied an isolate obtained from Passalora circumscissa (Sacc.) U. Braun, a significant foliar pathogen of Prunus spp., and their result revealed that the sequence clustered apart from sequences retrieved from the type species of Passalora ( $P$. bacilligera), so that the new genus Pruniphilomyces was introduced to accommodate Passalora circumscissa (Crous et al. 2020). In Iran, the causal agent of the leaf spot disease of Prunus spp. has been reported as Passalora circumscissa based on morphological data (Pirnia 2019). During this study, we prepared living cultures of several isolates of a passalora-like taxon associated with leaf spot diseases of cherry and sour cherry from different provinces of Iran, and the isolates were morphologically and molecularly analyzed. Both Bayesian and Maximum Parsimony analyses of concatenated alignments of three loci (LSU, ITS and RPB2) showed that the Iranian isolates obtained from Prunus spp. formed a highly supported clade assignable to Pruniphilomyces circumscissus (Fig. 1). Crous et al. (2020) described Pruniphilomyces on the basis of a single isolate. Our analyses were based on sequence data of nine isolates from different localities of Iran, which further confirmed the phylogenetic status of this taxon. To our knowledge, this study is the first molecular confirmation of Pruniphilomyces circumscissus for the Middle East. 
The other three taxa studied during this research were associated with leaf spot diseases of three forest trees in the Hyrcanian forest of northern Iran, including large leaf linden (Tilia platyphyllos), Caspian locust (Gleditsia caspica) and Mediterranean hackberry (Celtis australis). The Hyrcanian forests have always attracted the attention of biologists because they are ancient and an important biodiversity "hot spot" (Scharnweber et al. 2007; Yousefzadeh et al. 2017). In recent years, several molecular studies of fungal taxa occurring on forest trees in Hyrcanian forests of Iran revealed several novel mycosphaerellaceous species on some important trees of this area, e.g., Ramularia taleshina M. Bakhshi \& Arzanlou (Bakhshi and Arzanlou 2017) and Septoria taleshana M. Bakhshi \& Crous (Bakhshi et al. 2019) on Alder (Alnus subcordata), Septoria guilanensis M. Bakhshi, Zare \& Crous (Bakhshi et al. 2019) on Poplar (Populus deltoids), and Pseudocercospora ershadii M. Bakhshi, U. Braun \& Zare on Caucasian persimmon (Diospyros lotus) (Bakhshi et al. 2014; Braun et al. 2020). The introduction of a novel taxon, Prathigadoides gleditsiae-caspicae on Caspian locust, an important native forest tree in Hyrcanian region, further confirms the diversity of mycosphaerellaceous taxa in this area. The new taxon is morphologically and phylogenetically distinguished from previously described taxa belonging to the Mycosphaerellaceae.

An important and intriguing aspect of this study was the clear evidence that Prathigadoides gleditsiaecaspicae, although morphologically similar to species previously assigned to Prathigada, clustered in a separate clade within the Mycosphaerellaceae, reflecting a genus of its own. Previous molecular studies (Braun et al. 2013; Videira et al. 2017) have shown that Prathigada cratevae (current name $=$ Pseudocercospora cratevicola C. Nakash. \& U. Braun), the type species of this genus, clusters within the Pseudocercospora s. str. clade, thus Prathigada was reduced to synonymy with Pseudocercospora (Braun et al. 2013). These findings further illustrate the importance of using sequence data to clarify the phylogeny and taxonomy of taxa previously assigned to Passalora s. lat.

The genus Paracercosporidium includes two species on Tilia, namely P. microsorum and $P$. tiliae (Peck) U. Braun, C. Nakash., Videira \& Crous, which were previously placed in Passalora due to obclavate conidia (Crous and Braun 2003; Videira et al. 2017). Based on previous molecular studies, the two species clustered apart from the type species of the genus Passalora in a well-supported clade; therefore, Videira et al. (2017) introduced the new genus Paracercosporidium. Based on the phylogenetic analyses, the Iranian isolates obtained from large leaf linden (Tilia platyphyllos) in this study clustered within the Paracercosporidium microsorum clade. This is the first molecular confirmation of $P$. microsorum in Asia.

The isolates obtained from Mediterranean hackberry in this study, clustered together with sequences of Sirosporium celtidis. The genus Sirosporium is passalora-like in morphology, but treated as a separate genus confined to species with thick-walled dictyosporous conidia (Braun 1995; Crous and Braun 2003; Braun et al. 2013). So far, sequence data are only available for two species previously assigned to Sirosporium, viz., S. celtidis (treated as "Sirosporium" celtidis) and S. diffusum (treated as Ragnhildiana diffusa (Heald \& F.A. Wolf) Videira \& Crous), which clustered in separate clades within the Mycosphaerellaceae (Videira et al. 2017). However, sequence data are not available for the type species of the genus (S. antenniforme (Berk. \& M.A. Curtis) Bubak \& Serebrian), so that the status of this genus remained unresolved (Videira et al. 2017). The fact that the Iranian isolates of S. celtidis obtained from 
different provinces, also clustered with the isolates of this species collected from Algeria, Portugal and Italy (Videira et al. 2017; Fig. 1), further confirms the phylogenetic status of this species and its identification. Sequences retrieved from collections of $S$. antenniforme are urgently needed to reveal the true phylogenetic affinity of Sirosporium. In the event that $S$. celtidis is not congeneric with $S$. antenniforme, and sequences retrieved from the cercosporoid fungus on Celtis would form a distinct clade, the name Helicoceras Linder (Linder 1931) would be available for a separate genus. Monilia celtidis Biv. ( ${ }^{\circ}$ Sirosporium cletidis) is the type species of Helicoceras. Furthermore, the type species of Sirosporium, S. antenniforme, described from North America, and Monilia celtidis, described from Italy, have to be epitypified with ex-epitype cultures and ex-epitype sequences in order to determine these species and the corresponding genera genetically. We confirmed, the "Sirosporium" celtidis in Asia for the first time using molecular data.

Most passalora-like taxa obtained from Iran have been identified only based on morphological features and host range data, but living cultures and DNA data are still lacking. Accurate identifications of plant pathogenic fungi are pre-requisites for proper disease managements. As emphasized by different researchers, species identifications based solely on morphological characteristics often led to confusion in the taxonomy of cercosporoid fungi (Crous et al. 2013; Groenewald et al. 2013; Bakhshi et al. 2014, 2015a, 2018). Hence, comprehensive attempts to collect, cultivate and examine cercosporoid plant pathogens from diverse host plants in various geographical regions of Iran are urgently needed.

\section{Declarations}

\section{Acknowledgements}

We acknowledge the Research Deputy of the Iranian Research Institute of Plant Protection, Agricultural Research, Education and Extension Organization (AREEO), Tehran, Iran and Horticultural Science Research Institute, Citrus and Subtropical Fruits Research Center, Ramsar, Iran for financial support.

\section{Funding information}

This research was financially supported by Iranian Research Institute of Plant Protection, Agricultural Research, Education and Extension Organization (AREEO).

\section{Conflicts of interest}

The authors declare that they have no conflict of interest.

\section{Availability of data and material}


All sequence data generated in this study (Table 1) are available at GenBank (https://www.ncbi.nlm.nih.gov/genbank/). Alignments can be accessed via TreeBase (http://www.treebase.org)

\section{Authors' contributions}

Samples were collected by Mounes Bakhshi, and Hossein Taheri. Experiments, morphological and molecular analyses were conducted by Mounes Bakhshi. Rasoul Zare contributed to the data analyses of the taxa and funding acquisition. Uwe Braun contributed to the morphological analyses of the taxa. The first draft of the manuscript was written by Mounes Bakhshi and all authors commented on previous versions of the manuscript. All authors read and approved the final manuscript and have agreed to the published version of the manuscript.

\section{Ethics approval}

Not applicable.

\section{Consent to participate}

Not applicable.

\section{Consent for publication}

Not applicable.

\section{References}

1. Abdollahzadeh J, Groenewald JZ, Coetzee MPA., Wingfield MJ, Crous PW (2020) Evolution of lifestyles in Capnodiales. Stud Mycol 95:381-414

2. Bakhshi M (2019) Epitypification of Cercospora rautensis, the causal agent of leaf spot disease on Securigera varia, and its first report from Iran. FUSE 3:157-163

3. Bakhshi M, Arzanlou M (2017) Multigene phylogeny reveals a new species and novel records and hosts in the genus Ramularia from Iran. Mycol Prog 16:703-712

4. Bakhshi M, Arzanlou M, Babai-Ahari A (2012) Comprehensive checklist of Cercosporoid fungi from Iran. Plant Pathol Quar 2:44-55

5. Bakhshi M, Arzanlou M, Babai-ahari A, Groenewald JZ, Braun U, Crous PW (2015a) Application of the consolidated species concept to Cercospora spp. from Iran. Persoonia 34:65-86 
6. Bakhshi M, Arzanlou M, Babai-Ahari A, Groenewald JZ, Crous PW (2014) Multi-gene analysis of Pseudocercospora spp. from Iran. Phytotaxa 184:245-264

7. Bakhshi M, Arzanlou M, Babai-Ahari A, Groenewald JZ, Crous PW (2015b) Is morphology in Cercospora a reliable reflection of generic affinity? Phytotaxa 213:22-34

8. Bakhshi M, Arzanlou M, Babai-ahari A, Groenewald JZ, Crous PW (2018) Novel primers improve species delimitation in Cercospora. IMA Fungus 9(2):299-332

9. Bakhshi M, Arzanlou M, Zare R, Groenewald JZ, Crous PW (2019) New species of Septoria associated with leaf spot diseases in Iran. Mycologia 111 (6):1056-1071

10. Bakhshi M, Zare R (2020) Molecular confirmation of Nothopassalora personata causing leaf spot of peanut in Iran. Australas Plant Dis Notes 15 (9):1-4

11. Bakhshi M, Zare R, Jafary H, Arzanlou M, Rabbani nasab H (2021) Phylogeny of three Ramularia species occurring on medicinal plants of the Lamiaceae. Mycol Prog 20 (1):27-38

12. Braun U (1995) A monograph of Cercosporella, Ramularia and allied genera (phytopathogenic hyphomycetes): Vol. 1. IHW-Verlag, Eching, 333 pp

13. Braun U, Nakashima C, Bakhshi M, Zare R, Shin HD, Alves RF, Sposito M (2020) Taxonomy and phylogeny of cercosporoid ascomycetes on Diospyros spp. with special emphasis on Pseudocercospora spp. FUSE 6:95-127

14. Braun U, Nakashima C, Crous PW (2013) Cercosporoid fungi (Mycosphaerellaceae) 1. Species on other fungi, Pteridophyta and Gymnospermae. IMA Fungus 4:265-345

15. Carbone I, Kohn LM (1999) A method for designing primer sets for speciation studies in filamentous ascomycetes. Mycologia 91:553-556

16. Chupp C (1954) A monograph of the fungus genus Cercospora. Ithaca, New York, 667 pp

17. Clevenger J, Chu Y, Chavarro C, Botton S, Culbreath A, Isleib TG, Holbrook CC, Ozias-Akins P (2018) Mapping late leaf spot resistance in peanut (Arachis hypogaea) using QTL-seq reveals markers for marker-assisted selection. Front Plant Sci 9:83

18. Crous PW, Braun U (2003) Mycosphaerella and its anamorphs: 1. Names published in Cercospora and Passalora. CBS Biodiversity Series No. 1. Centraalbureau voor Schimmelcultures, Utrecht, the Netherlands, $571 \mathrm{pp}$

19. Crous PW, Braun U, Hunter GC, Wingfield MJ, Verkley GJM, Shin H-D, Nakashima C, Groenewald JZ (2013) Phylogenetic lineages in Pseudocercospora. Stud Mycol 75:37-114

20. Crous PW, Gams W, Stalpers JA, Robert V, Stegehuis G (2004a) MycoBank: an online initiative to launch mycology into the $21^{\text {st }}$ century. Stud Mycol 50:19-22

21. Crous PW, Groenewald JZ, Risede JM, Simoneau P, Hywel-Jones NL (2004b) Calonectria species and their Cylindrocladium anamorphs: species with sphaeropedunculate vesicles. Stud Mycol 50:415429

22. Crous PW, Summerell BA, Carnegie AJ, Wingfield MJ, Hunter GC, Burgess TI, Andjic V, Barber PA, Groenewald JZ (2009) Unravelling Mycosphaerella: do you believe in genera? Persoonia 23:99-118 
23. Crous PW, Summerell BA, Shivas RG et al. (2012) Fungal Planet description sheets: 107-127. Persoonia 28:138-182

24. Crous PW, Wingfield MJ, Schumacher RK, Akulov A, Bulgakov TS, Carnegie AJ, Jurjević Ž, Decock C, Denman S, Lombard L, Lawrence DP (2020) New and interesting fungi. 3. FUSE 6:157-231

25. de Hoog GSd, Gerrits van den Ende AHG (1998) Molecular diagnostics of clinical strains of filamentous Basidiomycetes. Mycoses 41:183-189

26. Douanla-Meli C, Langer E, Mouafo FT (2013) Fungal endophyte diversity and community patterns in healthy and yellowing leaves of Citrus limon. Fungal Ecol 6:212-222

27. Fernandes AF, de Miranda BEC, Duarte LL, Barreto RW (2013) Passalora stromatica sp. nov. associated with leaf spots of Tithonia diversifolia in Brazil. IMA Fungus 4:201-204

28. Groenewald JZ, Nakashima C, Nishikawa J, Shin H-D, Park JH, Jama AN, Groenewald M, Braun U, Crous PW (2013) Species concepts in Cercospora: spotting the weeds among the roses. Stud Mycol 75:115-170

29. Heystek F, Wood AR, Neser S, Kistensamy Y (2011) Biological control of two Ageratina species (Asteraceae: Eupatorieae) in South Africa. Afr Entomol 19(2):208-216

30. Hyde KD, Gareth EBJ, Liu JK, Ariyawansa H, Boehm E, Boonmee S, Braun U, Chomnunti P, Crous PW, Dai DQ Diederich P (2013) Families of Dothideomycetes. Fungal Divers 63:1-313

31. Katoh K, Standley DM (2013) MAFFT multiple sequence alignment software version 7: improvements in performance and usability. Mol Biol Evol 30:772-780

32. Kearse M, Moir R, Wilson A, Stones-Havas S, Cheung M, Sturrock S, Buxton S, Cooper A, Markowitz S, Duran C, Thierer T, Ashton B, Mentjies P, Drummond A (2012) Geneious Basic: an integrated and extendable desktop software platform for the organization and analysis of sequence data. Bioinformatics 28:1647-1649

33. Linder DH (1931) The genus Helicoceras. Ann Mo Bot Gard 18:1-8

34. Liu YJ, Whelen S, Hall BD (1999) Phylogenetic relationships among ascomycetes: evidence from an RNA polymerse II subunit. Mol Biol Evol 16:1799-1808

35. Maddison WP, Maddison DR (2018) Mesquite: a modular system for evolutionary analysis. Version 3.61. http://mesquiteproject.org

36. Minnis AM, Kennedy AH, Grenier DB, Rehner SA, Bischoff JF (2011) Asperisporium and Pantospora (Mycosphaerellaceae): epitypifcations and phylogenetic placement. Persoonia 27:1-8

37. Möller E, Bahnweg G, Sandermann H, Geiger HH (1992) A simple and efficient protocol for isolation of high molecular weight DNA from filamentous fungi, fruit bodies, and infected plant tissues. Nucleic Acids Res 20:6115-6116

38. Nylander JAA (2004) MrModeltest v 2.0. Program distributed by the author. Evolutionary Biology Centre, Uppsala University, Uppsala, Sweden

39. O'Donnell K, Kistler HC, Cigelnik E, Ploetz RC (1998) Multiple evolutionary origins of the fungus causing Panama disease of banana: concordant evidence from nuclear and mitochondrial gene 
genealogies. Proc Natl Acad Sci USA 95:2044-2049

40. Pirnia M (2019) Host range, geographical distribution and current accepted names of cercosporoid and ramularioid species in Iran. Curr Res Environ Appl Mycol J Fungal Biol 9(1):122-163

41. Rayner RW (1970) A mycological colour chart. CMI and British Mycological Society, Kew, Surrey, England, $34 \mathrm{pp}$

42. Ronquist F, Teslenko M, van der Mark P, Ayres DL, Darling A, Höhna S, Larget B, Liu L, Suchard MA, Huelsenbeck JP (2012) MrBayes 3.2: efficient Bayesian phylogenetic inference and model choice across a large model space. Syst Biol 61:539-542

43. Scharnweber T, Rietschel M, Manthey M (2007) Degradation stages of the Hyrcanian forests in southern Azerbaijan. Arch Nat schutz Landsch forsch 46(2):133-156

44. Schnabel A, McDonel RE, Wendel JH (2003) Phylogenetic relationships in Gleditsia (Leguminosae) based on ITS sequences. Am J Bot 90(2):310-320

45. Stewart EL, Liu Z, Crous PW, Szabo LJ (1999) Phylogenetic relationships among some cercosporoid anamorphs of Mycosphaerella based on rDNA sequence analysis. Mycol Res 103:1491-1499

46. Sung GH, Sung JM, Hywel-Jones NL, Spatafora JW (2007) A multigene phylogeny of Clavicipitaceae (Ascomycota, Fungi): identification of localized incongruence using a combinational bootstrap approach. Mol Phylogenet Evol 44:1204-1223

47. Swofford DL (2003) PAUP*: Phylogenetic Analysis Using Parsimony (*and other methods), version 4.0b 10. Sunderland, Massachusetts: Sinauer Associates

48. Tamura K, Stecher G, Peterson D, Filipski A, Kumar S (2013) MEGA6: Molecular Evolutionary Genetics Analysis Version 6.0. Mol Biol Evol 30:2725-2729

49. Thomma BP, Esse HP van, Crous PW, de Wit PJGM (2005) Cladosporium fulvum (syn. Passalora fulva), a highly specialized plant pathogen as a model for functional studies on plant pathogenic Mycosphaerellaceae. Mol Plant Pathol 6:379-393

50. Videira SIR, Groenewald JZ, Nakashima C, Braun U, Barreto RW, de Wit PJGM, Crous PW (2017) Mycosphaerellaceae - Chaos or clarity? Stud Mycol 87:257-421

51. White TJ, Bruns T, Taylor J (1990) Amplification and direct sequencing of fungal ribosomal RNA genes for phylognetics. in: Innis MA, Gelfand DH, Sninsky JJ, White JW (eds), A guide to molecular methods and applications. Academic Press, New York, 315-322 pp

52. Williams-Woodward JL, Copes WE (2017) Environmental factors impact temporal Passalora sequoiae conidia counts from Leyland cypress. J Phytopathol 165(7-8):538-546

53. Yousefzadeh H, Saidi A, Tayebi S, Kartoolinejad D, Naghdi R (2017) Molecular approach to determine taxonomic status of Septoria sp. causing leaf blotch of Castanea sativa in Hyrcanian forests. J For Res 28:661-670

\section{Figures}



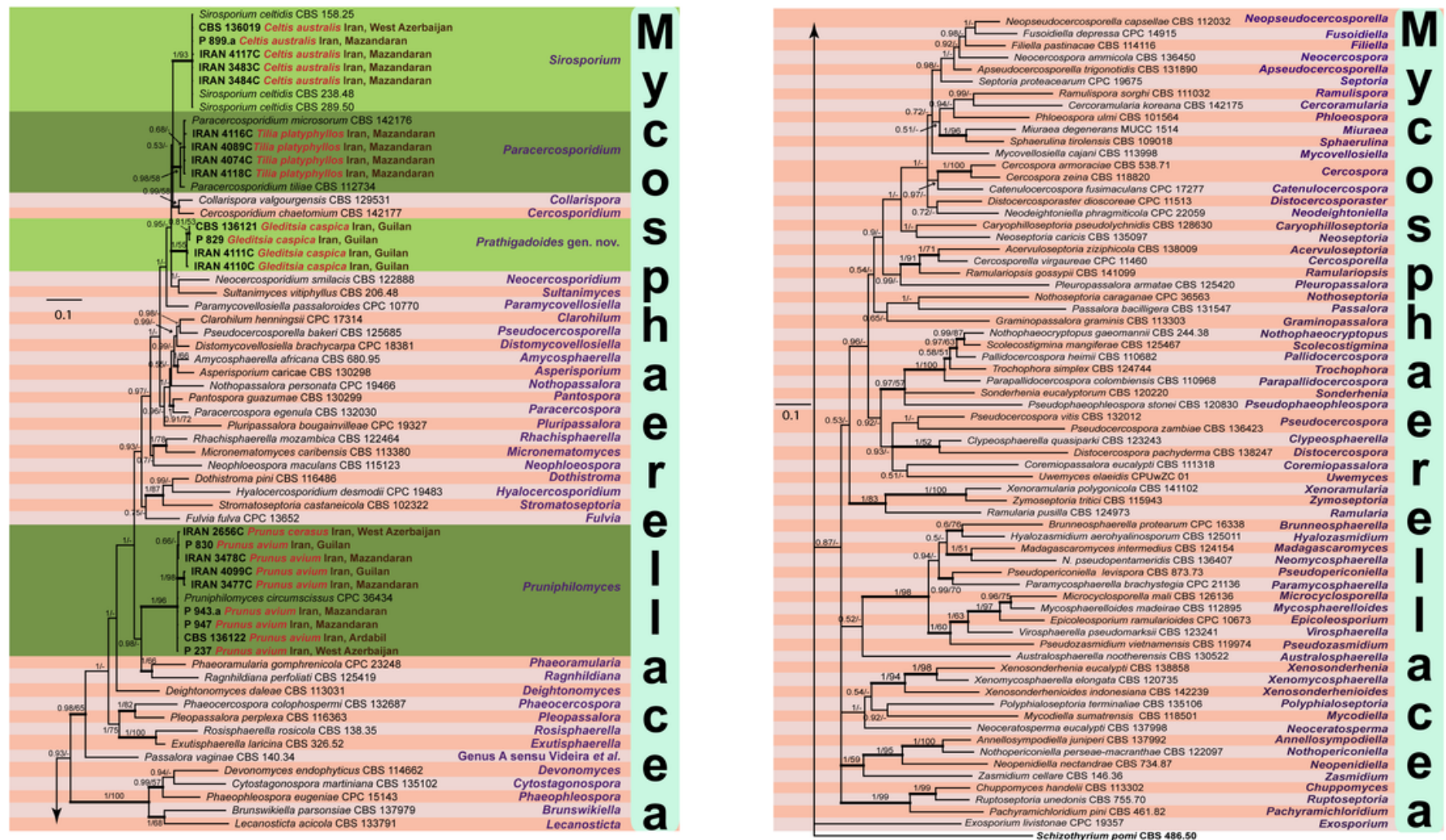

Figure 1

Consensus phylogram (50\% majority rule) resulting from a Bayesian analysis of the combined threegene (LSU, RPB2 and ITS) sequence alignment. The Bayesian posterior probabilities (PP) and Maximum Parsimony bootstrap support values (MP-BS) are given at the nodes (PP/MP-BS) and the scale bar indicates 0.1 expected changes per site. Thick bold branches represent the relationships present in the strict consensus parsimony tree. Lineages from Iran are indicated in green colored blocks and hosts and origin of the isolates in red and brown text, respectively. The tree was rooted to Schizothyrium pomi (CBS 486.50). 

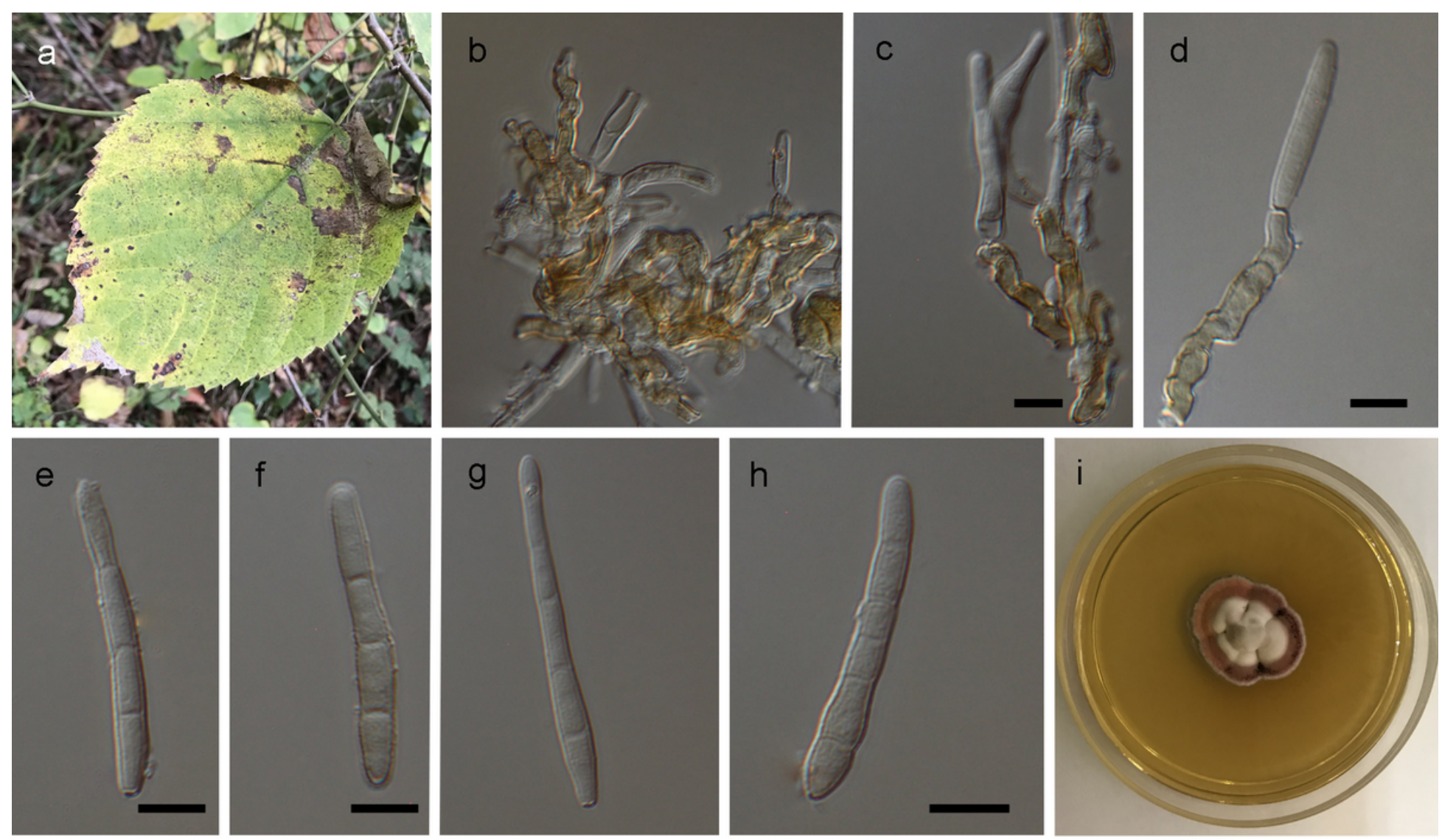

Figure 2

Paracercosporidium microsorum (IRAN 18055F). a Leaf spot symptoms on the host. b-d Fasciculate conidiophores. e-h Conidia. i Culture on MEA. Scale bars $=10 \mu \mathrm{m}$. 


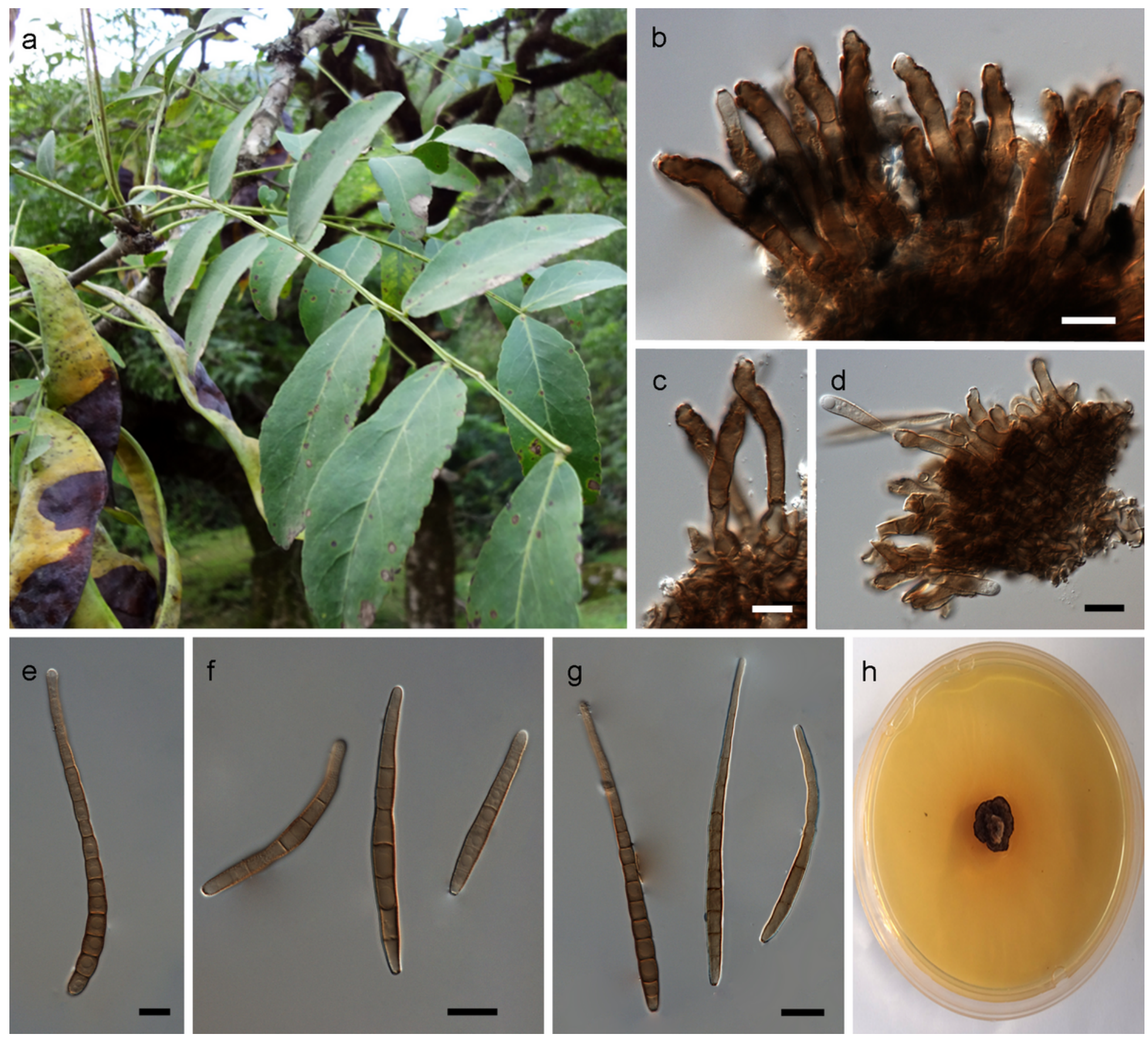

\section{Figure 3}

Prathigadoides gleditsiae-caspicae (IRAN 16460F). a Leaf spot symptoms on the host. b-d Fasciculate conidiophores. e-g Conidia. $\mathrm{h}$ Culture on MEA. Scale bars $=10 \mu \mathrm{m}$. 

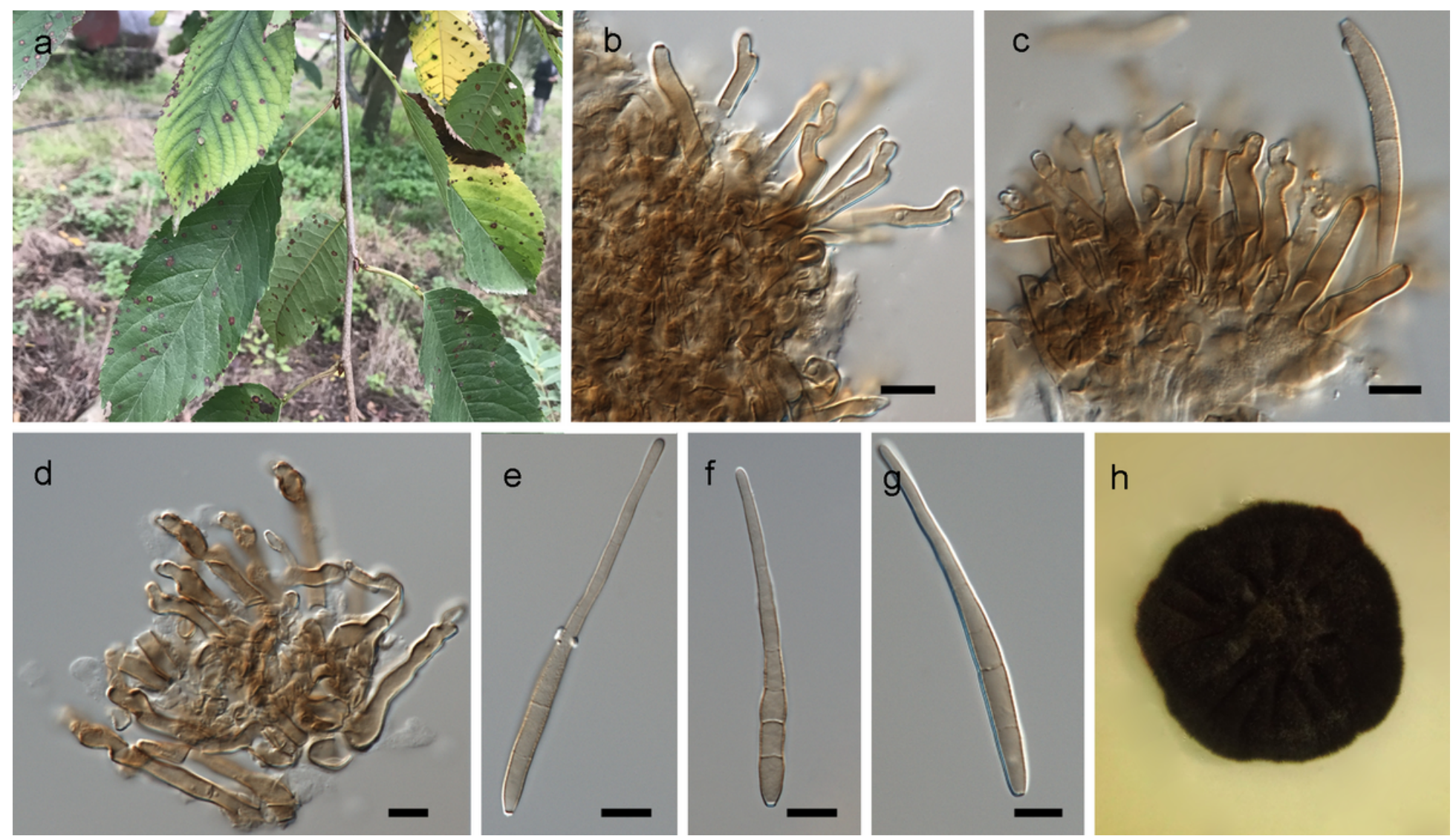

\section{Figure 4}

Pruniphilomyces circumscissus (IRAN 16459F). a Leaf spot symptoms on the host. b-d Fasciculate conidiophores. $\mathrm{e}-\mathrm{g}$ Conidia. $\mathrm{h}$ Culture on MEA. Scale bars $=10 \mu \mathrm{m}$. 

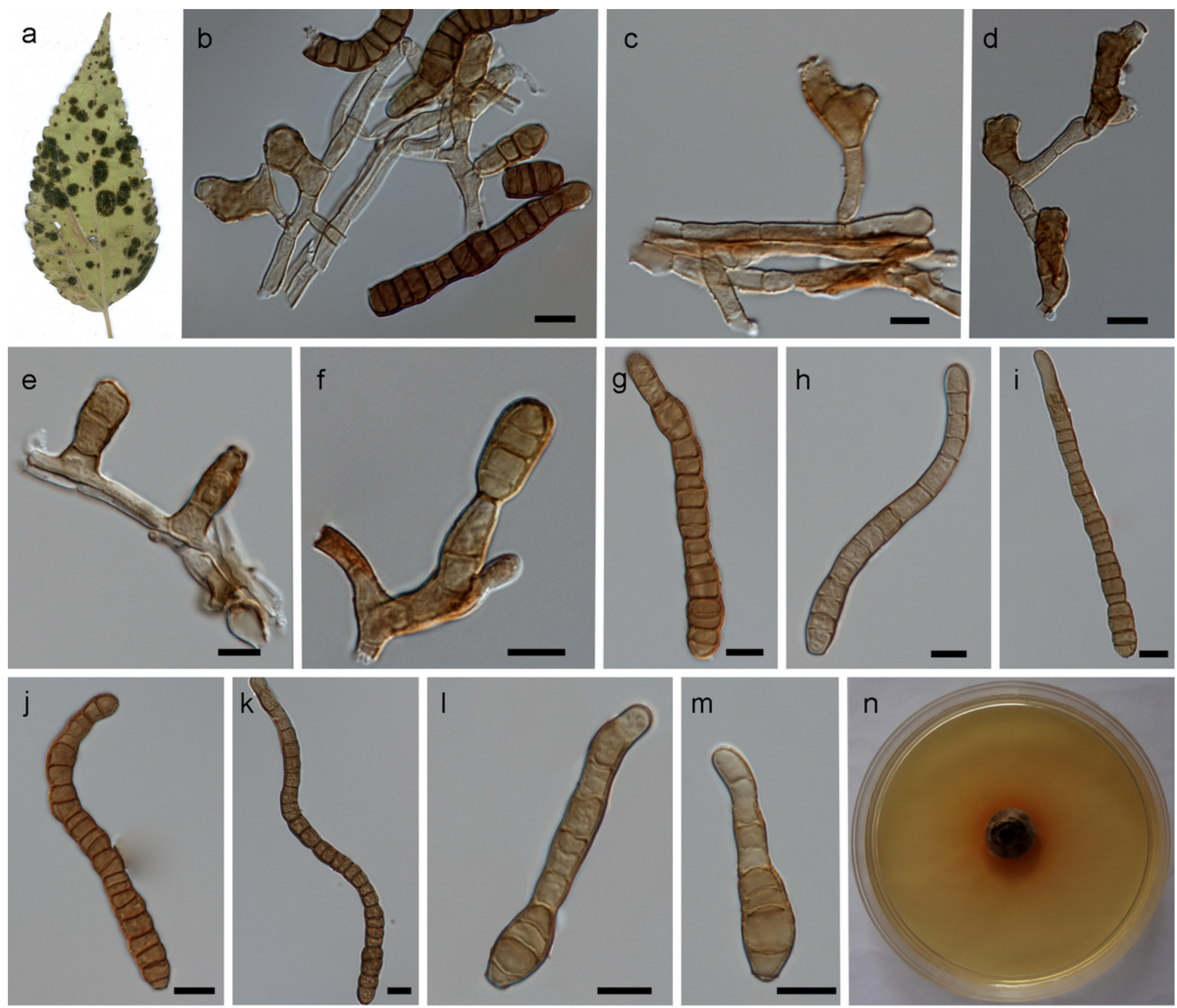

\section{Figure 5}

Sirosporium celtidis (IRAN 16465F). a Leaf spot symptoms on the host. b-f Hypha and conidiophores. $\mathrm{g}-\mathrm{m}$ Conidia. $\mathrm{n}$ Culture on MEA. Scale bars $=10 \mu \mathrm{m}$.

\section{Supplementary Files}

This is a list of supplementary files associated with this preprint. Click to download.

- Table1.xIs 